registration virtual reality for non linkage stereotactic surgery. Stereotact Funct Neurosurg 63:139-143, 1994

32. Turkington G, Jaszczak RJ, Pelizzari CA, et al: Accuracy of registration of PET, SPECT and MR images of brain phantom. J Nucl Med 34:1587-1594, 1993

33. Bidaut LM: Composite PET and MRI for accurate localization and metabolic modeling: A very useful tool for research and clinic. SPIE Medical Imaging V 1445:66-77, 1991

34. Gonzalez RC, Wintz P: Digital Image Processing. Reading, MA, Addison-Wesley, 1987

35. Barillot C: Surface and volume rendering techniques to display 3D data. IEEE Engineering in Medicine and Biology 12:111-119, 1993

36. Toga A (ed): Three-Dimensional Neuroimaging. New York, NY, Raven, 1990

37. Bidaut LM, Levivier M, Goldman S, et al: Multimodality stereotaxic correlation between XCT, PET, MRI and histoiogy for tumoral tissue evaluation in the brain. Proceedings of the 14th Annual International Conference of the IEEE-EMBS 1215-1216, 1992

38. Bookstein FL: Principal warps: Thin-plate splines and the decomposition of deformations. IEEE Trans Pattern Anal Mach Intell 11:567-585, 1989

39. Beier T, Neely S: Feature-based image metamorphosis. Comput Graph 26:35-40, 1992
40. Liang Z: Tissue classification and segmentation of MR images. IEEE Eng Med Biol 12:81-85, 1993

41. Wells WM, Grimson WEL, Kikinis R, et al: Adaptative segmentation of MRI data. Ayache $\mathrm{N}$ (ed): Computer Vision, Virtual Reality and Robotics in Medicine. New York, NY, Springer-Verlag, 1995, pp 59-69

42. Mangin J-F, Frouin V, Bloch I, et al: Automatic construction of an attributed relational graph representing the cortex topography using homotopic transformations. SPIE Mathematical Methods in Medical Imaging III 2299: 110-121, 1994

43. Sperling MR, Alavi A, Reivich $M$, et al: False lateralization of temporal lobe epilepsy with FDG positron emission tomography. Epilepsia 36:722-727, 1995

44. Gaillard WD, Fazilat S, White S, et al: Interictal metabolism and blood flow are uncoupled in temporal lobe cortex of patients with complex partial epilepsy. Neurology 45:1841-1847, 1995

45. Friston $\mathrm{KJ}$, Frith $\mathrm{CD}$, Liddle PF, et al: Comparing functional (PET) images: The assessment of significant change. J Cereb Blood Flow Metab 11:690-699, 1991

46. Verkindt C, Bertrand O, Perrin F, et al: Tonotopic organization of the human auditory cortex: N100 topography and multiple dipole model analysis. Electroencephalogr Clin Neurophysiol 96:143-156, 1995

\title{
New Digital Imaging Book Announcements
}

\author{
Picture Archiving and Communication Systems in Biomedical Imaging
}

\author{
by H.K. Huang, DSc
}

VCH Publishers, Inc.; 303 NW 12th Avenue; Deerfield Beach, FL 33442; Fax: 800-367-8247 Outside of North America, VCH Verlagsgesellschaft mbH; P.O. 10-11-61; 69451 Weinheim FRG.

$\$ 150.00$ plus handling. Call 800-961-8249. 489 pages.

\section{Imaging and Information Management: Computer Systems for a Changing Health Care Environment (May, 1996 Radiological Clinics of North America)}

\section{by Robert A. Greenes, MD, PhD, and Roger A. Bauman, MD}

W.B. Saunders Co.; Periodicals Marketing; Independence Square West; Philadelphia, PA 19106; Fax: 407-363-9661

$\$ 31.00$ (includes handling); add $\$ 6.00$ for airmail to Europe)

Call 800-654-2452. 248 pages. 